\title{
USE OF THE HEAT DISSIPATION METHOD FOR SAP FLOW MEASUREMENT IN CITRUS NURSERY TREES ${ }^{1}$
}

\author{
EDUARDO AUGUSTO GIRARDI², FRANCISCO DE ASSIS ALVES MOURÃO FILHO 3 , \\ JUAN SINFORIANO DELGADO-ROJAS ${ }^{4}$, JOÃO PAULO DE CAMPOS ARAÚJO ${ }^{5}$
}

\begin{abstract}
Sap flow could be used as physiological parameter to assist irrigation of screen house citrus nursery trees by continuous water consumption estimation. Herein we report a first set of results indicating the potential use of the heat dissipation method for sap flow measurement in containerized citrus nursery trees. 'Valencia' sweet orange [Citrus sinensis (L.) Osbeck] budded on 'Rangpur' lime (Citrus limonia Osbeck) was evaluated for 30 days during summer. Heat dissipation probes and thermocouple sensors were constructed with low-cost and easily available materials in order to improve accessibility of the method. Sap flow showed high correlation to air temperature inside the screen house. However, errors due to natural thermal gradient and plant tissue injuries affected measurement precision. Transpiration estimated by sap flow measurement was four times higher than gravimetric measurement. Improved micro-probes, adequate method calibration, and non-toxic insulating materials should be further investigated.
\end{abstract}

Index Terms: Brazil, Citrus spp., irrigation, plant propagation, screened production.

\section{USO DO MÉTODO DE DISSIPAÇÃO DE CALOR PARA A MEDIÇÃO DO FLUXO DE SEIVA EM MUDAS CÍTRICAS}

RESUMO - O fluxo de seiva poderia ser utilizado como parâmetro fisiológico para fomentar a irrigação de mudas cítricas em cultivo protegido pela estimação do consumo contínuo de água. Neste trabalho, reportamse os primeiros resultados, indicando o uso potencial e as limitações iniciais do método de dissipação de calor para medição do fluxo de seiva em mudas cítricas, em recipientes. Mudas de laranjeira-doce 'Valência' [Citrus sinensis (L.) Osbeck] enxertadas sobre limoeiro ‘Cravo' (Citrus limonia Osbeck) foram avaliadas por 30 dias, durante o verão. Sondas de dissipação de calor e sensores do tipo termopar foram construídos a partir de materiais prontamente disponíveis e de baixo custo para favorecer o acesso ao método por viveiristas. $\mathrm{O}$ fluxo de seiva apresentou alta correlação com a temperatura do ar dentro da estufa telada. Contudo, erros inerentes ao gradiente térmico natural e a injúrias nos tecidos do caule afetaram a precisão das medições. A transpiração estimada a partir da medição do fluxo de seiva foi quatro vezes maior do que a determinada por gravimetria. Microssondas adaptadas a plantas de porte reduzido, ajustes na calibração do método e uso de materiais atóxicos para isolamento térmico do conjunto devem ser futuramente investigados.

Termos para indexação: Citrus spp., irrigação, produção protegida de mudas, propagação.

\footnotetext{
${ }^{1}$ (Trabalho 200-09). Recebido em: 22-08-2009. Aceito para publicação em: 07-01-2010.

${ }^{2}$ Eng. Agr. DSc., Pesquisador A, Embrapa Mandioca e Fruticultura, Rua Embrapa, s/n, CEP 44.380-000, CP 007, Cruz das Almas-BA, girardi@cnpmf.embrapa.br

${ }^{3}$ Eng. Agr. PhD, Professor Associado, Departamento de Produção Vegetal, Escola Superior de Agricultura "Luiz de Queiroz" da Universidade de São Paulo, Av. Pádua Dias, 11, CEP 13.418-400, CP 09, Piracicaba-SP, francisco.mourao@usp.br (autor correspondente) ${ }^{4}$ Eng. Agr. DSc., Bolsista de Pós-Doutorado do CNPq / INCT em Engenharia da Irrigação, Departamento de Engenharia Rural, Escola Superior de Agricultura "Luiz de Queiroz" da Universidade de São Paulo, Av. Pádua Dias, 11, CEP 13.418-400, Piracicaba, SP, jsdrojas@esalq.usp.br

${ }_{5}^{5}$ Eng. Agr. DSc., Ajinomoto Interamericana, Centro de Planejamento e Desenvolvimento, Via Anhanguera, Km 131, CEP 13.480-970, Limeira,SP, joao_araujo@aia.ajinomoto.com
} 


\section{INTRODUCTION}

Citrus is the most cultivated fruit species in the World (FAO, 2009). In the main citrus producing countries, citrus nursery trees must be grown in screen houses in containers due to devastating diseases such as citrus variegated chlorosis, sudden death and huanglongbing (BOVÉ; AYRES, 2007). Just in Sao Paulo State, Brazil, there are 550 citrus nurseries with an annual production capacity of 30 millions nursery trees (FUNDECITRUS, 2008). Irrigation control is one of the most important practices in the nursery, directly affecting plant growth and profitability of the activity.

Although simple methods are used for nursery irrigation management, such as gravimetric analysis of container mass (BEESON, 2007), they do not provide information about plant water relations status. Moreover, this variable can be affected by substrate physical properties, root colonization conditions and variations among containers. Crops physiological variables measured in vivo are potential monitoring methods for irrigation scheduling (JONES, 2004). Sap flow measurement is among the most promising techniques and has been particularly studied in citrus species to estimate transpiration rates and to indicate water relations and drought effects (ORTUÑO et al., 2004a, 2006; ALARCÓN et al., 2005; DELGADO-ROJAS et al., 2007). These methods led to satisfactory comparisons with alternatives, such as trunk diameter fluctuations (ORTUÑO et al., 2004b), despite limitations which included errors inherent to sampling, scaling up of data to entire plant populations, strong influence of atmospheric conditions on sap flow, and need of constant calibrations (CERMÁK et al., 2004; JONES, 2004; BURGESS; DAWSON, 2008).

Sap flow measurement methods include heat pulse velocity, trunk segment or stem heat balance, heat field deformation and heat dissipation (CERMÁK et al., 2004). The heat dissipation method is also known as Granier's method (GRANIER, 1985). It has been applied for determining water consumption of woody plant communities through sap flow measurements directly obtained from selected individuals. It has also performed qualitatively well compared to other sap flow methods (GONZÁLEZALTOZANO et al., 2008).

We report here a first set of results indicating the potential use of the heat dissipation method for simple sap flow measurement in containerized citrus nursery trees, as this technique can also lead to transpiration estimation and physiological assessment of rootstocks.

\section{MATERIALS AND METHODS}

Four 12-month-old nursery trees of 'Valencia' sweet orange [Citrus sinensis (L.) Osbeck] budded on 'Rangpur' lime (Citrus limonia Osbeck) were selected for the investigation. Nursery plants were grown in $4.5 \mathrm{~L}$ polyethylene bags filled with composted pine bark and produced according to the production system recommended for Brazil (CARVALHO et al., 2005). Plants were transferred in January 2007 from a commercial citrus nursery to a screen house at Universidade de São Paulo, Piracicaba, SP, Brazil (22 $42^{\prime} 36^{\prime \prime} \mathrm{S}, 47^{\circ} 37^{\prime} 37^{\prime \prime} \mathrm{W}$, and $\left.520 \mathrm{~m}\right)$.

Heat dissipation probes were constructed based on materials described by Delgado-Rojas, 2003. The individual probe consisted of a surgical stainless steel needle with dimensions $0.80 \mathrm{~mm}$ x 30 mm (Becton Dickinson, Inc., Franklin Lakes, NJ, USA). The needle was reduced to $10 \mathrm{~mm}$ long with pliers and the sharp end was smoothed. Thermometric sensor selected was a thermocouple, by the manual interlacement of decoated copper and constantan wires, both $0.50 \mathrm{~mm}$ wide (Omega Engineering, Inc., Stamford, CT, USA). Each wire had a total length of $100 \mathrm{~mm}$, but the thermocouple (junction of the copper and the constantan wires) was along only 15 $\mathrm{mm}$ at one extremity. This thermocouple sensor was inserted through the needle from its back. Besides the thermocouple sensor, the probe was completed by a heat dissipation device. This consisted of the insertion of equivalent constantan wire through the needle, resulting in two extremities: extremity 1 was parallel to the thermocouple and extremity 2 was spirally rolled up to the needle. This segment was the heat dissipation component. In order to fix the structure, a knot was placed at the end of the constantan spiral and covered by araldite glue. The probe body apart from the heat dissipation component was covered by a $6 \mathrm{~mm}$ rubber tube, fixing the extremity 2 to the probe body. The complete probe could be constructed at a cost of less than US\$ 1.50/unity (January 2007 values). The probes were interconnected by extremities 1 of the constantan wires.

Plants were drilled at 3 and $13 \mathrm{~cm}$ high, always on the rootstock trunk segment, with a $3 \mathrm{~mm}$ wide hand drill. Plants had diameter slightly less than $12 \mathrm{~mm}$ at those heights, thus the hole was $10 \mathrm{~mm}$ deep. A segment of type 304 stainless tube (Caporal Inc., São Paulo, SP, Brazil), with $2.5 \mathrm{~mm}$ of external diameter and $0.25 \mathrm{~mm}$ of thickness, was inserted in each hole. Probe was then inserted inside the stainless tube after filling with thermal paste for uniform heat dissipation. The whole structure and hole were protected with a silicone layer which also performed 
as heat insulating material.

Thermocouple sensors were connected to a four channel data logger (CR-10X, Campbell Scientific Inc., North Logan, UT, USA) by copper wire with four $0.14 \mathrm{~mm}^{2}$ wire strains (Tiaflex Inc., São Paulo, SP, Brazil). One guide was used as a ground wire. All connections were welded and covered with insulating tape. Power source was $110 \mathrm{v}$ electrical current and the heat dissipation probe received a constant power of only 0.1 watt. Electric resistance in the probe corresponded to $1.375 \mathrm{Ohms}$, but the reference temperature for the thermocouple was not measured at the copper/constantan wires junction.

Polyethylene bags and the rootstock trunk of the plants were covered by aluminum foil in order to avoid water evaporation from the potting mix, and for better heat insulation. Plants were placed on concrete benches and fully exposed to sunlight. Daily irrigation was performed with $150 \mathrm{~mL}$ per bag through a straw. Bags were daily weighted at 09:00 $\mathrm{h}$ with the use of a digital kitchen scale ( $1 \mathrm{~g}$ precision) for transpiration measurement. Evaluation was carried out for 30 days. Air and sap temperatures were registered by the data logger in $15 \mathrm{~min}$ intervals. Sap flow was calculated by Granier's equation (G+, 1985), and an effective xylem section was considered equivalent to the whole trunk section area. Air temperatures in the screen house and sap flow were correlated by Pearson's Correlation Coefficient.

\section{RESULTS AND DISCUSSION}

Granier's method was efficient for detecting stem temperature variations and, consequently, sap flow, during the evaluation period (Figures 1 and 2). Temporary sap flow depletion was registered during periods of maximum stress usually observed after midday (Figure 1), and it may be related to stomatal closure. Air temperature inside the screen house highly correlated to sap flow $\left(r^{2}=0.758\right)$ (Figure 2$)$. However, there are large variations in sap flow associated to small variations in temperature (Figure 2 ), probably as a result of greater influences due to differences in radiation.

Daily transpiration determined by gravimetric measurements was uniform during evaluation period and similar between trees $\left(130 \pm 45 \mathrm{~mL} \mathrm{plant}^{-1}\right.$ day $\left.^{-1}\right)$. However, daily sap flow in the same period was 530 $\pm 210 \mathrm{~mL} \mathrm{plant}^{-1}$ day $^{-1}$ when calculated by Granier's equation. This over estimation could be partially explained by the wide variation of individual temperature measurements due to the natural thermal gradient, with night temperature noises also observed (Figure 3). Natural thermal gradient is usually higher close to soil or substrate surface, as in the case of this evaluation, and it results from irradiance and external temperatures interferences along plant tissues (DELGADO-ROJAS, 2003). A third non-heated probe was installed between the initial ones, but it did not minimize the error estimate.

Other error source includes the diminished size of the probe used in this evaluation, which is usually 20 to $40 \mathrm{~mm}$ long in other studies, and this consequently results in an extremely reduced power enhancement that is sensitive to energy fluctuations. As a result of the small diameter $(12 \mathrm{~mm})$ of the nursery trees, the probes might have caused physiological or/and physical disturbs and increased exposition to higher influence of temperature variations. Consequently, imprecise sap assessment was performed. Therefore, sap flow measurement in this experiment should not be considered exact or reliable for irrigation decision, and could only initially describe sap flow behavior in nursery plants.

After the probes were disconnected, severe damages and necrosis in the stems were observed on the probe installation segments. Although the leaves did not show any symptoms of wilting, the stem injuries probably affected sap flow and significantly altered measurements, resulting in a potential constraint for this method. Trunk or branch segments with diameters of less than $5 \mathrm{~cm}$ are usually not used for the heat dissipation method, as a result of both inadequate determination of effective xylem section and greater influence of the natural thermal gradient (CERMÁK et al., 2004; JONES, 2004; DELGADOROJAS et al., 2007; BURGESS; DAWSON, 2008). Sap flow measurements may also be influenced by the relation between the interfered section by the probes and the trunk section area.

In order to elucidate if injuries were caused by the probes themselves, healthy stem segments were covered with silicone layer without stainless tube or probe insertion. Similar bark damages were initially observed just ten days after silicone application, suggesting that this substance is highly toxic to young citrus tissues. Usual solvent for commercial silicones is acetic acid, which may present herbicide properties (manufacturer information). Therefore, alternative insulating materials should be further evaluated. 


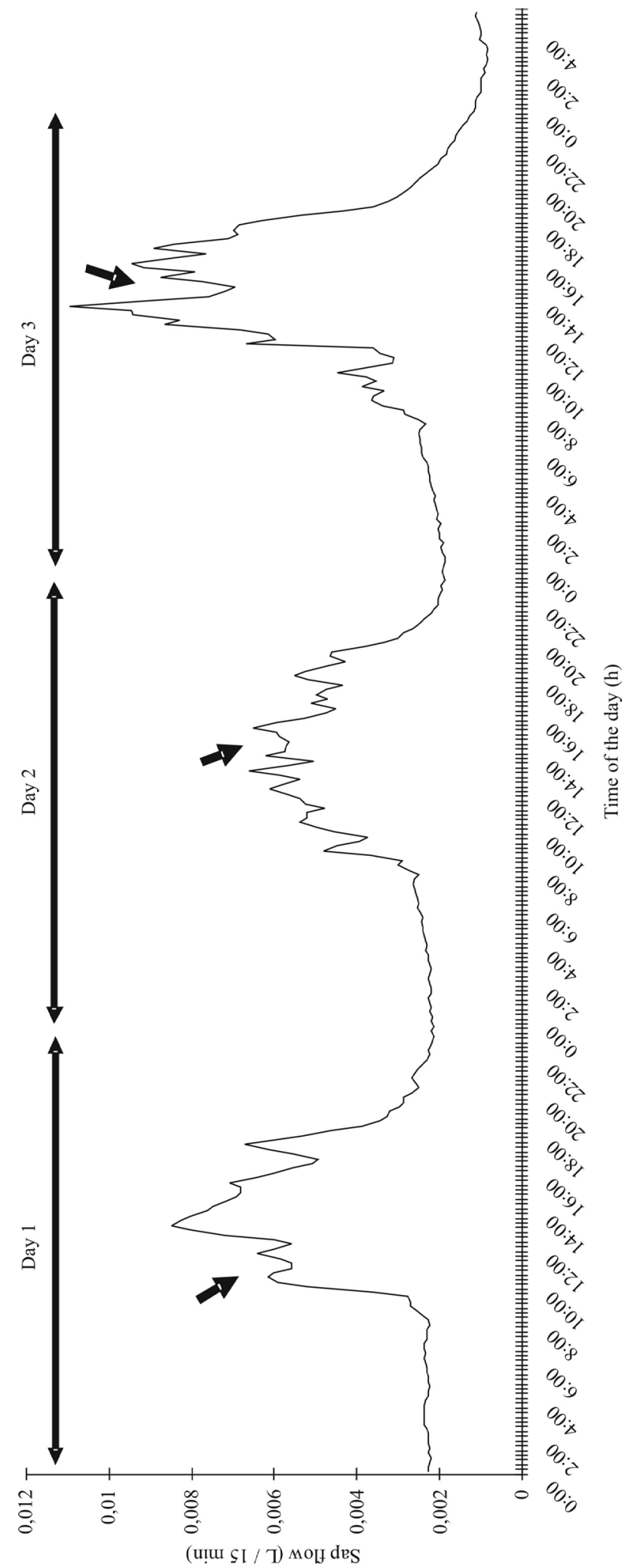

FIGURE 1 - Sap flow of screen house grown citrus nursery trees estimated by the heat dissipation method. Each data point is the mean of four values. The arrows indicate sap flow depletions (PiracicabaSP, Brazil, 2007). 


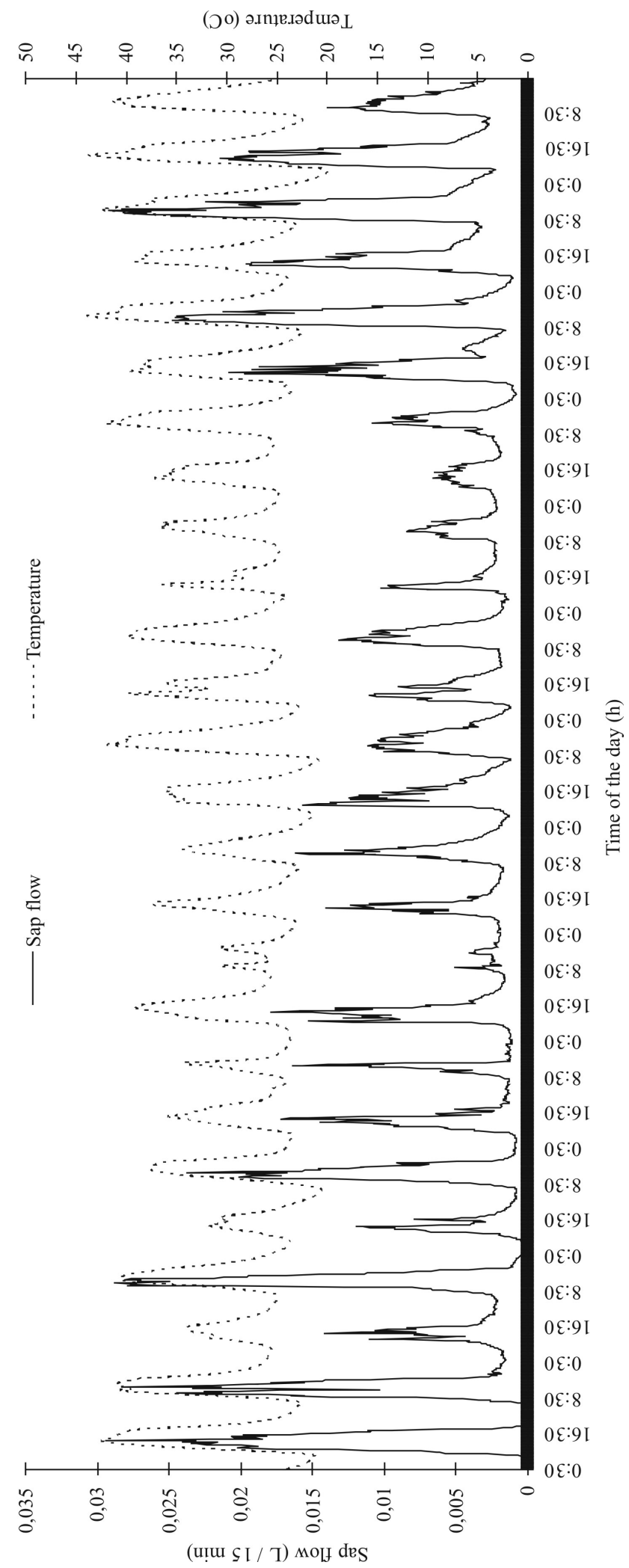

FIGURE 2 - Air temperature inside the screen house and sap flow of citrus nursery trees estimated by the heat dissipation method in a 28 days period. Each data point is the mean of four values (Piracicaba-SP, Brazil, 2007). 


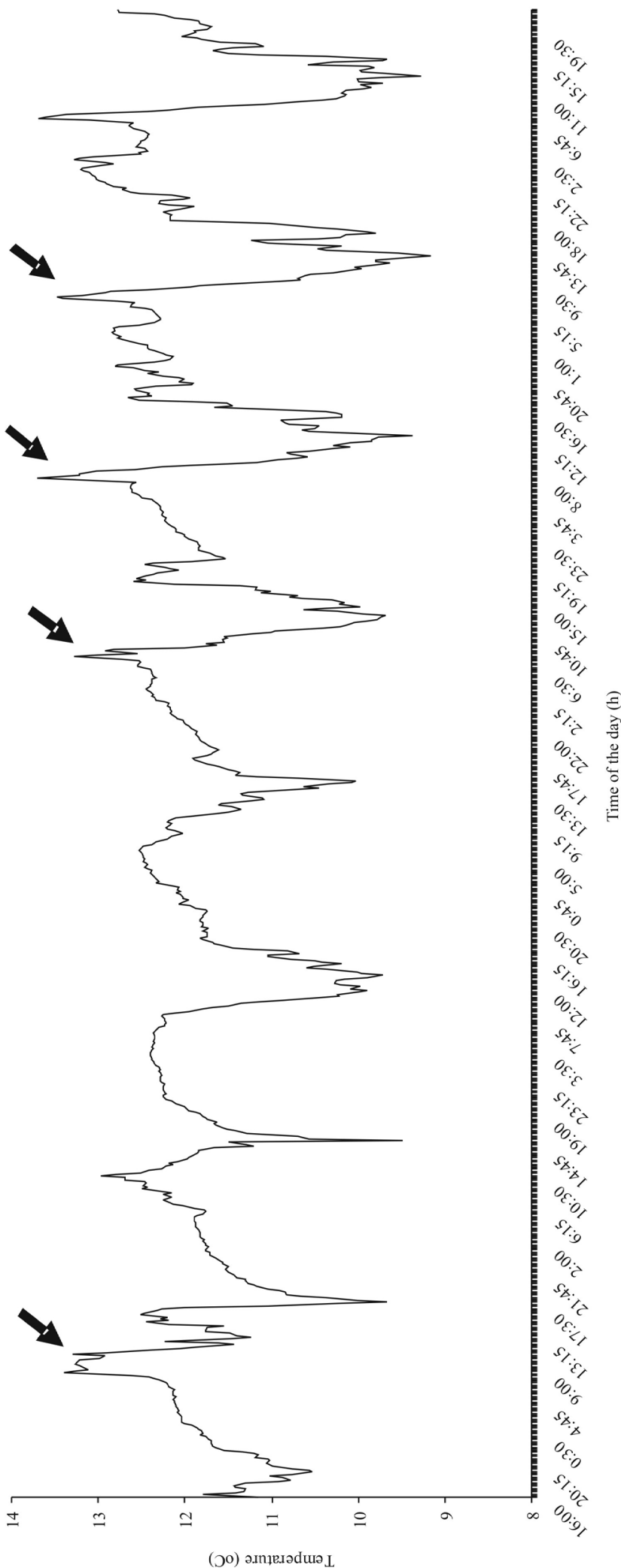

FIGURE 3 - Temperature variations between heat dissipation probes inserted in citrus nursery trees trunks. The arrows indicate night temperature noises, when sap flow is expected to be interrupted. This error is attributed to the natural thermal gradient along plant tissues. Each data point is the mean of four values (Piracicaba-SP, Brazil, 2007). 


\section{CONCLUSION}

Although further investigation is required, the first set of experiments described here indicate the potential use of the heat dissipation method for sap flow measurements and estimation of water consumption for citrus nursery trees, which could lead to a more accurate irrigation management in the industry. This method could also be applied in rootstocks assessment for water deficit tolerance. Non-toxic substances for citrus tissues should be evaluated for use as heat insulating materials, and micro-probes construction could reduce errors inherent to the method. Adequate calibration must also be taken in order to minimize natural thermal gradient. The advantages of the method are easy accessibility, low costs of materials and simple construction of probes.

\section{ACKNOWLEDGEMENTS}

The authors thank to Dr. Luiz Roberto Angelocci (ESALQ/USP) and Dr. Jairo Augusto de Campos Araújo (FCAV/UNESP) for the supply of equipments and location necessary to carry out this work, and to Dr. Jay L. Schell for critical comments. The first author thanks to Fundação de Amparo à Pesquisa do Estado de São Paulo (FAPESP) for fellowship.

\section{REFERENCES}

ALARCÓN, J.J.; ORTUÑO, M.F.; NICOLÁS, E.; TORRES, R.; TORRECILLAS, A. Compensation heat-pulse measurements of sap flow for estimating transpiration in young lemon trees. Biologia Plantarum, Dordrecht, v.49, n.4, p.527-532, 2005.

BEESON, R.C. Determining plant-available water of woody ornamentals in containers in situ during production. HortScience, Alexandria, v.42, n.7, p.1700-1704, 2007.

BOVÉ, J.M.; AYRES, A.J. Etiology of three recent diseases of citrus in Sao Paulo State: Sudden death, variegated chlorosis and huanglongbing. IUBMB Life, Oxford, v.59, p.346-354, 2007.

BURGESS, S.S.O.; DAWSON, T.E. Using branch and basal trunk sap flow measurements to estimate whole-plant water capacitance: a caution. Plant and Soil, Dordrecht, v.305, n.1-2, p.5-13, 2008.
CARVALHO, S.A.; GRAF, C.C.D.; VIOLANTE, A.R. Produção de material básico e propagação. In: MATTOS, D. JR.; NEGRI, J.D.; PIO, R.M.; POMPEU, P. JR. (Ed.). Citros. Campinas: Fundag, 2005. p.281-318.

CERMÁK, J.; KUCERA, J.; NADEZHDINA, N. Sap flow measurements with some thermodynamic methods, flow integration within trees and scaling up from sample trees to entire forest stands. Trees: Structure and Function, Heidelberg, v.18, p.529-546, 2004.

DELGADO-ROJAS, J.S. Avaliação do uso do fluxo de seiva e da variação do diâmetro do caule e de ramos na determinação das condições hídricas de citros, como base para o manejo da irrigação. 2003. 129 f. Tese (Doutorado em Irrigação e Drenagem) - Escola Superior de Agricultura "Luiz de Queiroz”, Universidade de São Paulo, Piracicaba, 2003.

DELGADO-ROJAS, J.S.; ANGELOCCI, L.R.; FOLEGATTI, M.V.; COELHO FILHO, M.A. Performance of thermal dissipation probe in the measurement of transpiration of young plant of Tahiti acid lime. Engenharia Agrícola, Jaboticabal, v.27, p.404-413, 2007.

FAO. FAOSTAT. Disponível em: $<$ http://faostat.fao, org>. Acesso em: 15 jan. 2009.

FUNDECITRUS. Viveiros e mudas. Disponível em: $<$ http://www.fundecitrus.com.br $>$. Acesso em: 15 set. 2008

GONZÁlEZ-ALTOZANO, P.; PAVEL, E.W.; ONCINS, J.A.; DOLTRA, J.; COHEN, M.; PAÇO, T.; MASSAI, R.; CASTEL, J.R. Comparative assessment of five methods of determining sap flow in peach trees. Agricultural Water Management, Amsterdam, v.95, n.5, p.503-515, 2008.

GRANIER, A. A new method of sap flow measurement in tree stems. Annales des Sciences Forestières, Les Ulis, v.42, n.2, p.193-200, 1985.

JONES, H.G. Irrigation scheduling: advantages and pit-falls of plant-based methods. Journal of Experimental Botany, Oxford, v.55, n.407, p.24272436, 2004 
ORTUÑO, M.F.; ALARCÓN, J.J.; NICOLÁS, E.; TORRECILLAS, A. Comparison of continuously recorded plant-based water stress indicators for young lemon trees. Plant and Soil, Dordrecht, v.267, p.263-270, 2004a.

ORTUÑO, M.F.; ALARCÓN, J.J.; NICOLÁS, E.; TORRECILLAS, A. Interpreting trunk diameter changes in young lemon trees under deficit irrigation. Plant Science, Shannon, v.167, p.275-280, 2004b.
ORTUÑO, M.F.; GARCÍA-ORELLANA, Y.; CONEJERO, W.; RUIZ-SÁNCHEZ, M.C.; MOUNZER, O.; ALARCÓN, J.J.; TORRECILLAS, A. Relationships between climatic variables and sap flow, stem water potential and maximum daily trunk shrinkage in lemon trees. Plant and Soil, Dordrecht, v.279, p.229-242, 2006. 